\title{
On Power and Open-ended Process of Social Change
}

\section{HECTOR CUADRA-MONTIEL* \\ SANDRA CARMONA**}

*PhD. El Colegio de San Luis, A.C. México. Correo electrónico: h.cuadra.montiel@gmail.com; hector.cuadra@colsan.edu.mx **PhD. Universidad Autónoma de Nuevo León. México. Correo electrónico: carmona.uanl@gmail.com

\section{Abstract}

This article aims to identify the factors which trigger social change, and what makes such possible. The argument opens by presenting a critical analysis of rational choice institutionalism for understanding the process of change. It is immediately followed by a section which argues that the identification of immanent power in all social relations represents the core factor for explaining the open-ended social processes of change. Furthermore, since social processes entail social changes, it is recognized that the interactions among ideational, material, structural and agential elements within time and space are crucial. For, it is argued that neither political, nor economic trends determine the outcomes of processes, because public and private functions and activities can play complementary roles of one another. It is also stressed that the internal appropriation of change contributes to the incremental, punctuated and evolutionary character of social change.

\section{Keywords}

Social change - Power - Structure - Agency - Social relations 
Perspectivas Revista de Ciencias Sociales - ISSN 2525-1112|Año 3 No. 6 Julio-Diciembre 2018, pp. 78-100

\section{Introduction}

What this article aims to make evident is the strong political element in every step, decision, election, choice or inaction. Politics encompasses both the public and the private spheres, where the intensity of power immanent in all social relations, on the one hand, and the degree of commodification of economic activities, on the other, prove useful for tracing a general, albeit imprecise, picture of the tendencies and countertendencies in play. Thus, some simple, but at the same time important and uncomfortable, questions urgently need to be answered: What triggers social change? How does social change happen? What are the factors which make changes evident?

Although neither a definitive, nor a conclusive answer to the question of what triggers change is attempted here, an attempt is made to spell out some of the theoretical and empirical issues which must characterise the debate. The processtracing of change needs to be carefully conducted. ${ }^{1}$ Suffice to say broad distinctive features are taken into account; however, it is important to stress that it is not the aim of this research to provide a detailed typology of the features of social change. On the contrary, only a few broad characteristics are considered in so far as they may best capture the general tendencies and countertendencies of social processes.

The features of change which are analyzed here include two dimensions of change which complement each other. Some mainstream literature has dealt with the material dimensions of change, whereas the ideational dimension has risen in importance (Blyth, 1997; Hall, 1989; Hay, 2000 and 2002; and Wendt, 1992 and 1999). Moreover, material and ideational transformations can range from being adaptive and slow-paced to incremental and more radical and rapid change. The reformist motion cannot be identified as easily as the crisis moments when in the perception of observers the pace and succession of change accelerates. Another aspect to consider is how social, political and economic factors interplay and impact upon each other. It is the constant repetition of relevant actions and omissions which helps to forge path-dependent dynamics. For the repetition of both active and passive courses of action contribute towards setting, in the medium and long term, how costly would it be to opt for other alternatives. In other words, as economists assert, transaction costs prove crucial. In addition to these features, their origins, either domestic or external, are undoubtedly worth considering, for they can be acknowledged as opportunities or constraints for agenda-setting, decision-making, preference and context shaping in the eyes of the actors in context.

As a starting point for considering the above questions, it is crucial to make clear from the outset the features of the approach adopted here. This allows us to identify windows of opportunity and constraint which could open up or cancel out alternative courses of action, both active and passive. The strategic selectivity affects both structures and agency, due to the fact that the context does not determine the outcomes and nor does the agency always realise her or his goals. A famous passage, often cited, from Marx's Eighteenth Brumaire of Louis Bonaparte reads "...men make their own history, but not of their own free will; not under circumstances they themselves have chosen..." (Hay 2002:17). This influential 
statement is neatly divided in two parts. Apart from the structural limits of action evidenced in the second half of the sentence, the first highlights the vital role which actors have in shaping and influencing the course of events. The limits to this capacity are also acknowledged, since unintended consequences run parallel to the intended goals. Nevertheless, the crucial aspect is, without any doubt, the potential and capacity of the agents for transforming the context they live in. The dialectical interaction between structures and agency never leaves either unaltered. Their interaction modifies each element. Nonetheless, it is important to acknowledge that the degree of change is never uniform as it varies in each specific situation. Therefore, the impact of the transformations is uneven, since the capability and resources remain unequally distributed in any dialectical interaction or relationship.

Figure 1. Social processes of change crucial interactions

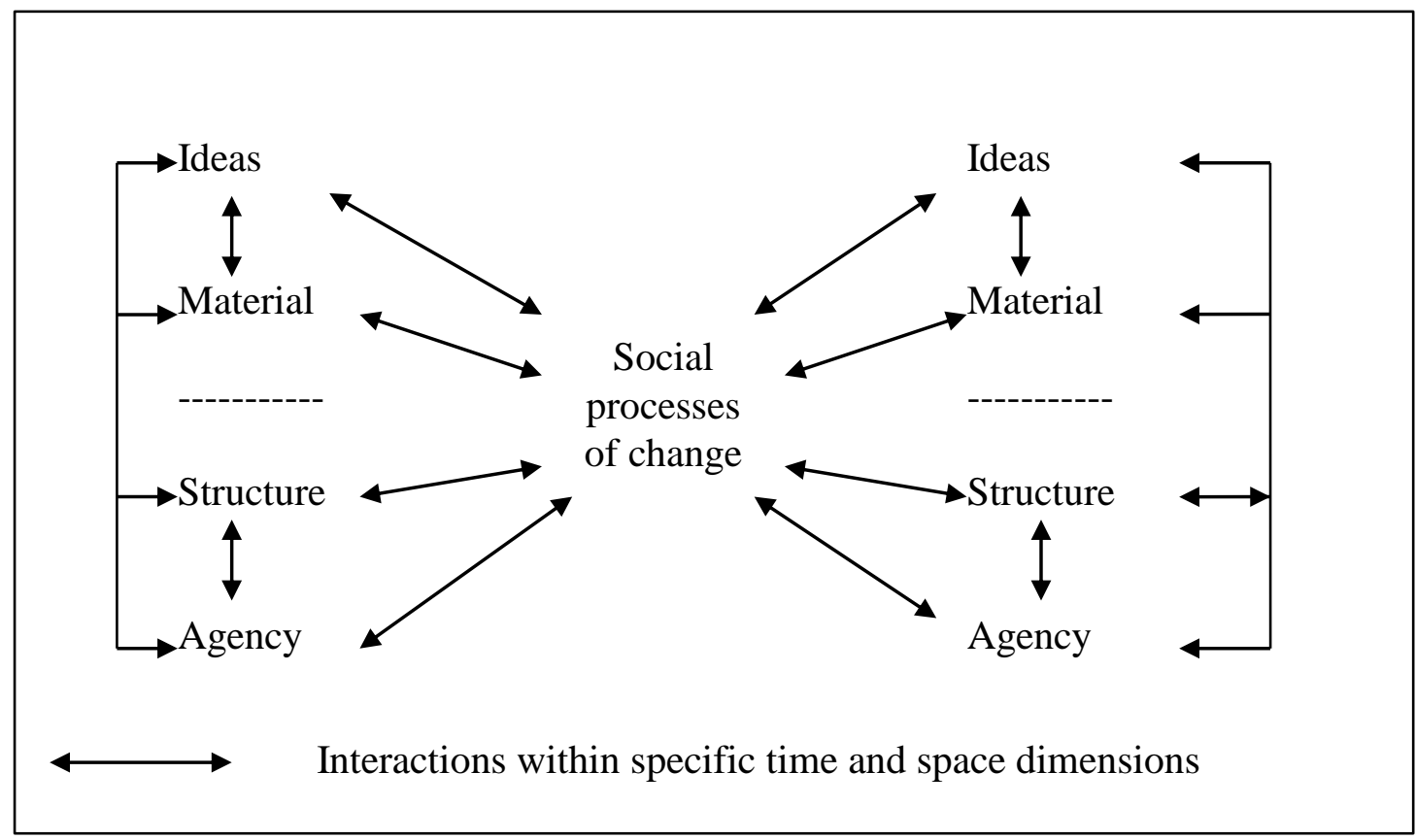

Throughout this work the conception of social, political and economic change is perceived to embrace the social system itself as a sequence of interrelated changes. It is the succession of various stages over time and the aggregated result of various components within the spectrum of potential change. The ever-changing nature of social dynamics varies over time and is also case-specific, multidimensional and multilevel (Sztompka, 1993). A broad range of possibilities and scenarios takes place within the spatio-temporal dimensions, where the material and the ideational spheres interact with each other and also with a vast range of structures and agency. It is important to identify the vital elements that take part in the punctuated evolution apparent to us. ${ }^{2}$ For a graphical representation of the analytical distinctiveness of this 
Perspectivas Revista de Ciencias Sociales - ISSN 2525-1112|Año 3 No. 6 Julio-Diciembre 2018, pp. 78-100

approach, in particular, the material and ideational elements which, are made by situated agents in strategically selective contexts within specific spatio-temporal locations, see Figure 1 above. It is to this perspective in more detail that we now turn.

\section{The core factor of change}

The analysis of change has been approached from different angles. One of the most widely used, although it is not exempt from controversy, is institutionalism. According to this view, institutions provide the rules of any given society. Their main purpose is to reduce the margins of uncertainty and to clearly define and delimit the boundaries of individuals' choices (North, 1990a). Before proceeding it is important to stress the fact that institutionalism has been used as a generic label for embracing analytical approaches with important common characteristics, but also with some fundamental differences. ${ }^{3}$ While for some analysts the sharing of common analytical ground could be used as a platform for supplementing and reinforcing the approaches (Hall et al., 1996), ${ }^{4}$ for certain others, although some collaboration might seem desirable at first glance, its prospects are more limited under closer scrutiny due to unavoidably incompatible premises (Hay et al., 1998). ${ }^{5}$

In particular, one of the fundamental deficiencies of institutionalism is the inadequate attention granted to the analytical distinction between structure and agency. Structure and agency are not features of the real world. Rather, they work as heuristic tools for analysis of social, political and economic interaractions. There are loads of stories for structure and agency to be told. Crucial as they are, the ontological distinctiveness of rational choice institutionalism, sociological institutionalism and historical institutionalism make any 'crude synthesis' of them all impossible (Hay et al., 1998).

The acknowledgment that policies are meant to work as producers of specific resources and incentives, impacts upon governmental spheres and nongovernmental ones too. The dialectical interaction between structures and agency, and between the material and the ideational spheres, provides both general and specific feedback, which in turn make their way, albeit modified through the processes, towards the transformation of State capacities (Cuadra-Montiel 2009, 2012 and 2016).

The suggestion that specific incentives derived from policies induce individuals to take actions makes those particular policy developments path-dependent. That is, the claim that certain patterns of inertia make the only feasible option for individuals a very narrow range of choice, is a quite evident, although by no means exclusive, characteristic of rational choice institutionalism. Lock-in policy effects are supposed to render previously viable alternatives implausible, followed by a somehow passive acceptance of previous decisions and courses of action (Pierson, 1993). ${ }^{6}$ The logic of the inevitability of unfettered market compulsion as defended by hyperglobalists is an example (Ohmae, 1990 and 1996; Held et al., 1999; Hay et al., 2000a). Since this argument has been used to justify the unavoidability of the priorities of such marketoriented economic strategies as liberalization, privatization and deregulation, it is to a closer scrutiny of one of the institutionalisms that we now turn. 
Just as different analytical focuses are pursued under the banner of institutionalism, rational choice institutionalism, also labelled neoclassical institutionalism, is not a uniform perspective in its own right (Gilpin, 2001). There are different exponents and research agendas grouped under the rational choice institutionalist label. Nevertheless, some consensus arises over the concepts of bounded rationality, and the utility maximizing actor realizes his or her goals more effectively through institutional action. However, it does not take long for the goal seeking individual to realise that institutions constrain, enable and shape his/her behaviour (Peters 1999). ${ }^{7}$ Despite discrepancies, one of the most important agreements amongst institutionalists concerns what institutions are. For them, institutions are sets of rules, either formal or informal, which serve to establish a stable structure within which human interactions take place facilitating 'rational' conduct. The importance of institutions stems from a mix of incentives and transaction costs. Some transaction costs may be increased, and some others decreased, in order to favour certain aims and courses of action. It is in this sense that the evolution of a society through time is shaped by institutional change. Institutions are, then, "...the rules of the game in a society or, more formally... the humanly devised constraints that shape human interaction..." (North, 1990a:3). The influential work of the Nobel laureate and author of Institutions, Institutional Change and Economic Performance, seeks to explain how institutions create structural incentives which influence and shape the direction of change, incrementally modifying the institutional framework in a path-dependent way. In other words, North's view is a structurally directed or induced top-down analysis of institutional change, in which the institutional framework is a precondition for the performance of an economy. According to his argument, it follows that the addition of a large number of economies makes possible mass markets (1990a). ${ }^{8}$ The role markets play is essential for social change. Not only markets are socially embedded, they are also locus where countless interactions among actors take place. $^{9}$ It is there that endless preferences take shape and where inifinite transactions are realized. Markets are so fluid and dynamic that never remain as they once were. They are never in a static condition as they constantly evolve and transform institutional features and the contexts agents are situated in.

It is clear that changes in the ideational sphere are qualitatively important. Suffice it to say here that specific governmental policies can deliver tangible benefits to citizens. Medical care, welfare and education services, to mention only a few, may result in significant material benefits for many people. This gives some economic sectors impetus, both in terms of economic gains and losses, growth and a reduction in the provision of material goods and of the infrastructure they need to use. Since there is no unique direction of change, the material elements and factors interact and influence one another, hence both need to be considered.

Even though rational choice institutionalism recognizes that the rules of the game are creations of human agency, and builds on the foundation of their choices, gives too little weight to the fact that agents are able to trigger social change. Rational choice institutionalism in general, and North's argument in particular, transfigure the agential starting point of that approach, by appealing to a deterministic structural logic in the 
end. Furthermore, North proceeds without even conceding that the choices which individuals make modify the contexts which they are in. The farthest this rational choice institutional perspective goes is to suggest that organizations can induce change (North, 1990a:73-82). In his view, organizations bind groups of individuals by some common purpose to achieve specified objectives. Thus, political, economic, social and educational organizations operate in a fluid dynamic of evolution influenced by the institutional framework (1990a). Still, this is not the same thing as saying that actors, either individual or collective, could be a factor of change themselves. Since power is embedded in all social relations, agency in context finds herself/himself able to modify and influence the structure in which (s)he is situated. In other words, power is not exclusively hierarchic and structurally determined all the way down from the top (Foucault, 1976, 1977 and 1979). Each situation is case specific and dependant on a multitude of factors; nevertheless, each and every agent, both individual and collective, has the potential to influence, promote and achieve changes at different levels of the structure. Yet, it is of utmost importance to acknowledge that all resources are differentially distributed.

There are some important omissions in the rational choice institutionalist analysis and conceptualization of change. A striking weakness, especially in North's work, is the lack of explicit mention of power and the way in which it influences social structures and agents. For according to Foucault, power is the core factor of social change immanent in all social relations. This is schematically shown in Figure 2 below. Even though, for North, there is an implicit acknowledgement of authority and power, it is never spelled out in his famous book. The economic discourse of institutions as rules in a society which function to decrease uncertainty and to define and limit the set of choices of individuals is clear, as is his model of treating social interactions as costs. ${ }^{10}$ What it is not clear at all, since there is no explicit mention of it in his analysis, is the role which authorities play, in particular, and the exercise of power more generally in his analysis. Since institutions are treated as the rules of the game, the fact that power issues and dimensions are taken for granted must be examined, debated and challenged. For institutionalism, rules are given for individuals to follow and delimit their feasible choices; although those sets of rules do not cancel out alternative courses of action. Furthermore, collective and individual agents could identify some rules as incompatible with some of their preferences. Hence, actors could exercise their freedom to choose. In case no option matches their preferences, clearly their demands still need to be satisfied. In this sense, Cuadra-Montiel (2007a) highlights the relevance of a mode of governance through networks, where there is enough room for multiple actors, agendas, authorities, norms and levels to interact among themselves. 
Figure 2. Power: the core factor of social change

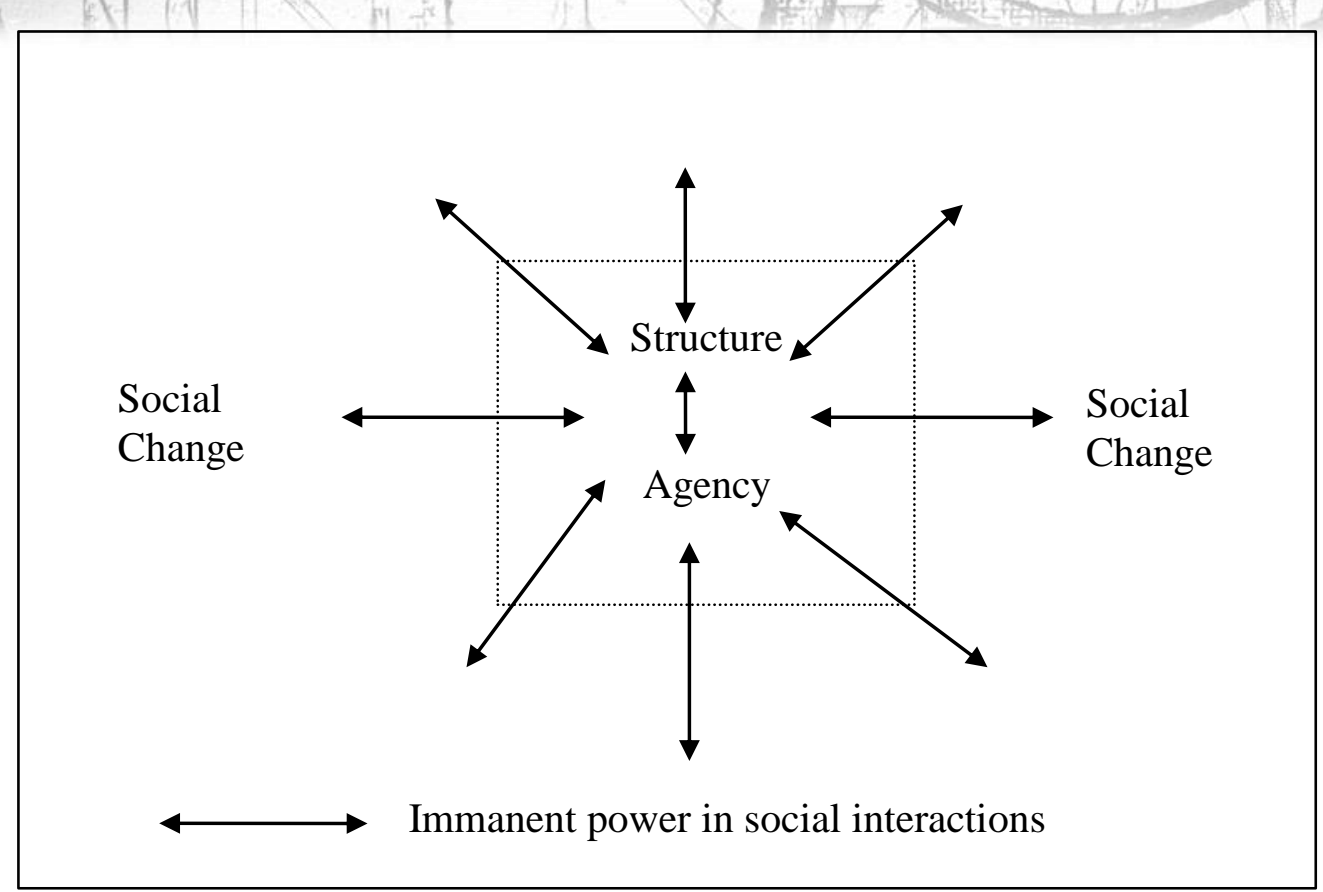

Since one of the clear ways in which structural power can be exercised is through the production and reproduction of knowledge, this in turn, at least in some academic and government circles, has emphasized a concern for stability. This is why it does not come as a surprise that some mainstream theories are oriented towards the preservation of the status quo. Dominant forms of ideas and knowledge work as an instrument for maintaining dominance (Gill, 1997). Nonetheless, it is important to recall that agents are never powerless, because power is embedded in all social relations (Foucault, 1976 and 1977). Moreover, for Foucault power has no privileged origin and no a priori essence. It is articulated with discourses and institutions, at the same time as it is integrated into different strategies. According to this view, power has been characterized as a conjunctural producer of knowledge in all social relations. Power and knowledge directly imply one another (Jessop, 1990; and Hay, 2002). In this sense, actors, both individual and collective, have in their own hands the means and ability to influence their courses of action to affect particular outcomes.

It is important to bear in mind that a range of different factors and agency take part in the decision-making processes, the definition of the agenda, and the shaping of the preferences and contexts (Lukes, 1974). Not only is the enforcement of rules clearly a matter of power, but the agenda and the context they are in tell us much about whose interests and which actors they are privileging. Rational choice institutionalism goes beyond some of the simplistic assumptions of orthodox neoclassical economics and perceives the world as a multiple equilibrium market (North, 1990a). Nonetheless, incomplete information and poor feedback, on the one hand, and 
uncertain outcomes and changing preferences over time, on the other, are also situations which elude simplistic models. In short, a complex mix of formal and informal norms, rules and constraints make for strategic selectivity, never determining the outcomes though.

It is interesting to recall that for rational choice institutionalism, change can be reduced to a marginal adjustment in the institutional framework, where the adjustments in relative prices and tastes alter norms and ideologies. ${ }^{11}$ According to this explanation, change is the outcome of innumerable short-term decisions made by political and economic entrepreneurs shaping the performance of the institutional framework. The way in which those decisions affect the rules of the game could be both direct and indirect, incrementally making long-term changes more evident. Since the focus of this article is on the peaceful processes of change, relevant external shocks such as war are not under scrutiny here. In this sense, institutional change is one of the two ways in which economies and societies evolve. The other is technological change, which could be assigned in turn as a material sphere. For rational choice institutionalists the incremental pace of change works to recontract and to capture potential gains, shaping the depth and extent of the alterations or reforms. In this neoclassical economics-oriented explanation of rational choice institutionalism, institutional change appears as the underlying concern for the set of hierarchic constraints associated with stability. In a manner consistent with this view, the cost of change increases each time according to the strength of the interactions, whenever either a minor reform or a radical transformation is attempted (North, 1990a). Hence, path dependence favours repeated courses of action and inaction.

\section{Social processes entail social changes}

Institutional change cannot, and must not be, translated as equivalent to a transformation of the State. For the State is a social process always in the making with patterns of punctuated evolution and therefore, its analysis must not be reduced to a simple institutional set of rules (Cuadra-Montiel, 2007a). The reforms of institutions can however, be accounted as one of the elements of the social processes; they might be a necessary, but never a sufficient, condition for a fundamental change or reorientation of the State. There are degrees of institutional change which could vary from almost insignificant to major ones. Since institutions account only for a portion of the non-material elements of the State, a transformation of one of its parts, or even some of them do not account for the whole of the social body, especially for all of its ideational and material elements.

Elements of change can be addressed in terms of their material and ideational dimensions, and in terms of their structural and agential aspects. Yet, the facilitation of some courses of action does not guarantee that any expected outcome will occur as intended. There are always unintended consequences, because perfect control of all the variables is impossible in the real world.

In spite of the similarities in the temporality patterns of social processes, history evolves in a punctuated fashion, never repeating itself. On the contrary, the contingency of the social interactions and the indeterminacy of the factors at play 
always leave the door open for uncontrollable elements. Taking a closer look at the discovery of different social processes, their similar characteristics over time are always quite revealing of the elements, factors, tendencies and countertendencies at play. The detail of the features reveals dissimilarities which must not be overlooked. It is important to stress that the very contingency which agents bring to the social processes also represent an important social trigger of change. This agency promoted change accounts for elements of variation and indeterminacy impossible to find in structural accounts and explanations of change. Moreover, changes move in different, sometimes contradictory directions. Multidirectional patterns of punctuated evolution cover a more comprehensive spectrum, which, depending on power factors, could help determine the depth of the transformation along the political and economic axes. Some changes may result in effects which are superficial and shallow, whereas some others as might turn out to be deep and fundamental transformations.

Even though they are not always easy to identify, the processes of social change are facilitated and constrained by very different sorts of power related factors, i.e., institutions, individuals, regulators, specific actions, deliberate omissions, information, ideas, governments, firms, etc.; all play a role in the ever evolving processes of social change. They are case specific and could be exercised both directly and indirectly within specific contexts. Additionally, they may embrace the whole gamut of material and non material elements and of agency and non-agency factors.

Acknowledging history matters, especially for explaining long-term economic change, rational choice institutionalist authors claim that it is possible to assess economic performances. Because path-dependent interactions decisively contribute to shaping structure-agency and material-ideational interactions at different levels, it comes as no surprise that the longer the time periods under scrutiny, the more evident patterns of change become. Rational choice institutionalism and historical materialism are very different theoretical approaches and their emphasis, concepts, and focus do not match. The prescriptions of rational choice institutionalism depart widely from those of historical materialism (North, 1990a). Some exponents of rational choice institutionalism, aiming for efficiency, clearly tend to favour stability, therefore exhibiting a pro-status quo deterministic and structuralist logic (Hay, 2002). It is vital to stress the analysis of power as the core factor of change, as this acknowledges the fact that social processes entail social change. The focus of the following section is on the tangible and intangible dimensions of social change. Without claiming that it is an exclusive power to highlight non-observables, the structure and agency analytical referent, also stresses the way in which material conditions and circumstances are intertwined and interwoven with ideational factors. This concern regarding the processes of social change is the theme of the following section

\section{Material - Ideational dynamics}

It is important to make clear that the theoretical structure and agency distinction, on one side, and the material and the ideational distinction on the other, though 
Perspectivas Revista de Ciencias Sociales - ISSN 2525-1112|Año 3 No. 6 Julio-Diciembre 2018, pp. 78-100

intertwined and interwoven in practice, can be separated for analytical purposes. Structure and agency are not features of the real world out there, they are mainly heuristic tools to artificially dissect a complex reality. To a different degree all schools of thought in social science have either an explicit or an implicit position on the role of ideas and material factors in their explanations. Either they prioritise one over the other, or, adopting a more dialectical perspective, they give equal weight to the role of ideas and material factors (Hay, 2002).

However, the recognition of the interplay between these factors is by no means new. For instance, Gramsci's seminal conception of hegemony highlighted the role of ideas and cultural processes; it provided an explanation of the indirect, albeit consensual exercise of power and opened up avenues of research (Gill, 1993). Even though there has been a preliminary discussion above about ideational elements and institutions, we need now to turn to an assessment of these fundamental analytical dimensions. In so doing, less explicit mention of the rules of the game is undertaken, while the stress is now on ideas as intangible preconditions and their causal and constitutive role in the production of outcomes (Watson, 2000). ${ }^{12}$ In this sense, flows of knowledge and ideas could have various consequences; however, the explicit use and implicit aims of knowledge and ideas vary in important ways.

The literature of international relations and institutionalism with their different concerns and perspectives, have varied in how valuable they consider the ideational dimension to be. The inclusion of ideas has broadened the analytical horizon of the disciplines. Consider 'paradigm shifts' in economic policy already identified with different degrees of impact on the bureaucracy, the political agenda and society. When referring to 'paradigm shifts', Hall makes a classification of their importance. Whilst third order change implies radical modifications not only in the setting of policy, but also in the aims and instruments employed to guide policy which is associated with a shift in governing paradigms, first and second order changes are viewed as social learning adjustment policies which do not challenge the terms of a given policy paradigm at all (Hall, 1993). ${ }^{13}$ Nevertheless, the feasibility of those shifts depends on the combination of various economic, political and administrative factors (Hall, 1989); for which international relations and institutionalism offer different emphases.

The dialectical interactions between the intangible dimensions of ideas and the tangible dimensions of the material sphere have recently gained increased prominence in international relations literature since the rise of constructivism. The claim that structures and political realities can be socially constructed and the exploration of the issues of identity, rank among the priorities of this theoretical perspective (Checkel, 1998).

Within the political science literature in general, and international relations authors in particular, Wendt's work is considered to be an example of 'thin constructivism' because even though it recognises the dialectical relationship between the ideational sphere and the material one, it gives greater priority to the latter factors than to the former. A 'thicker' constructivist position emphasizes more the role of ideas over the material world, or to put it more simply, is more 'ideas all the way down' (Wendt, 
1999). Interestingly, constructivists have contributed to stretch the debate on the role of ideas within international relations, an academic discipline which in the last few decades has systematically either omitted or given a low priority to the contributions which ideas can make in analysing the international arena.

Wendt engages in a debate over the material or social nature of structures, criticizing realism, the mainstream theory of International Relations, for its incapacity to address structural change. He claims that, in addition to material phenomena, ideas, beliefs and expectations shape the international structure. In addition, he suggests that the identities and interests of the States are constructed by the international system itself. According to this point of view, anarchy cannot be a structure since 'it is nothing', and has no logic apart from the process, because it is merely conceived as a constitutive element. In Wendt's famous words it is just 'what States make of it' (1992 and 1999).

Moreover, in his view the interaction of States is responsible for the reproduction and transformation of the international system. Wendt argues that it is ideas and their distribution within the social structure which determine not only the meaning and content of power, but the strategies to pursue interests and the interests themselves. ${ }^{14}$ Following his argument, culture tends to reproduce itself, becoming a non-deterministic self-fulfilling prophecy. Thus, the material-ideational distribution of the content and meaning of power and interests presupposes the discursive formation of ideas, knowledge, culture and beliefs (Wendt, 1999:92-138).

Even though Wendt considers the State to be socially constructed, he also acknowledges the corporate agency constituted by social and internal structures. In his perspective, the properties of the State which he refers to include its institutional and legal order, its society, its territory, its organization with sovereignty claiming a monopoly on the legitimate use of force; however, he does not go any further than this (Wendt, 1999; and Cuadra-Montiel 2007a).

The role of ideas and discourse should not be overlooked. The importance of this intangible dimension proves crucial because ideas can have an independent causal and constitutive role in the production of political, economic and social outcomes. Any agent, acting on his or her perceptions of the real world, contributes to trigger the creation of realities which they are meant to reflect.

This is of crucial importance, since the current trend of governance moves towards the depoliticization of not only the most evident decision-making procedures, such as the counting of votes and representation of the population, but the implementation of otherwise unpopular and clearly unpalatable political and economic tasks, such as the reduction of welfare provisions or tax cuts. This takes for granted that the logic of inevitability is clearly equivalent to an exercise of power. Shaping not only public preferences but the context in which public and private courses of action are selected is complemented by a conscious political strategy of restricting the spectrum of feasible choices. Furthermore, the lack of accountability enjoyed by external constraints favours the reproduction of the status quo and provides a structural deterministic aura which neglects the role of the agency in shaping and influencing the course of events (Cuadra-Montiel, 2011). Clearly this is not the case, 
Perspectivas Revista de Ciencias Sociales - ISSN 2525-1112|Año 3 No. 6 Julio-Diciembre 2018, pp. 78-100

because socially constructed processes depend on ideational and material inputs, whose interaction results in contingent and never identical material and ideational outcomes.

The way in which ideas function as self-fulfilling prophecies is nothing new, though it is only recently that it has attracted attention from political analysts. Consider for instance the way laissez-faire and free trade were promoted and allowed by the State to take their course. The political promotion of the market economy could only take place within a socially constructed market society in more or less a similar fashion in the $19^{\text {th }}$ century as it does nowadays. The daily reinforcement of these assumptions takes a strong path-dependent channel, which increases the transaction costs of changing or reversing a given course of action. This is not to say, however, that change is impossible and that the modification or abandonment of any assumption cannot take place. On the contrary, alternative ideas can also become self-fulfilling prophecies and can therefore trigger change; but this could not happen to them all. The vital aspect to bear in mind is that ideas are a necessary, but never a sufficient condition for triggering or obtaining social change. The material conditions and factors complement any initiative (Cuadra-Montiel, 2012 and 2016).

Two important intangible elements are then the ideas which actors hold and agency's perceptions of the material contexts. Both of them are crucial for the selection of feasible courses of action, and they are also appropriated through discourses; which, in turn, influence and are influenced by subsequent ideas and perceptions. Unsurprisingly, both structures and agents play a decisive role in the reproduction of ideas and perceptions.

On the one hand, structures tend to favour specific courses of action, by providing either incentives or signals, or else by omitting alternative routes. To say that the context in which the actors situate themselves privileges some specific courses of action is not to argue for structural determinism. Since the decisions which individuals make cannot be isolated from their context and from the perceptions of what surrounds them, the shaping of preferences and contexts within which courses of action are selected is a clear and evident act of power (Lukes, 1974).

However, contrary to the prevalent assumptions in mainstream international relations and orthodox neoclassical economics; neither a self-interested rational unitary actor, nor a symmetrically informed individual, matches theory with practice. ${ }^{15}$ Information asymmetries have been recognised as quite a common problem and to have negative effects on the selection which a collective or individual agency makes (Akerlof, 1970; Rotschild et al., 1976; and Spence, 1973).

The interaction between strategically selective contexts and situated agents with ideas and perceptions produces clear ideational and material outputs. Due to some intended and unintended consequences, both outputs are in turn partially transformed inputs of a subsequent output. The ideas which agents hold and their perceptions of the strategically selective contexts help them read where they stand. It does not come as a surprise that due to the lack of complete information, actors need to interpret the contexts in which they find themselves. In this sense, agency makes assumptions about the world which surrounds them to decide which courses 
of action to take, if any, or whether to do nothing at all. Therefore, ideas and beliefs, though immaterial, are both real and have real effects with a mix of ideational and material consequences (Hay, 2002 and 2000). Thus, ideas, beliefs and perceptions do have an independent, causal and constitutive role in the production of outcomes. Consequently, they trigger without determining the behaviours and practices of actors. These, in turn, take part in the cumulative and incremental processes of social change, through the exercise of power embedded in all social relations by agency.

The perception and interpretation of the way in which actors see themselves in context is crucial for selecting strategies or courses of action. Evidence clearly shows that the implementation of policy changes and governmental priorities is often preceded by ideological shifts on the part of people who hold key decision-making posts (Hall, 1989 and 1993). Furthermore, not only are structures selective but they are never determinate in directing certain strategies over others. Yet, they operate in a similar way to discourses. The selection of certain preferences does not imply the unquestioned adoption of certain discourses through which they might be appropriated. Thus, ideas and discourses are key components and promoters of the processes of social change with a significant material impact (Hay, 2002, 2000, and 1996).

\section{Internal and external origins}

Even though the incentives for change may come from different sources, it is the actors themselves who make them relevant to change, whenever they reproduce specific passive or active behaviour contributing to forge path-dependent courses of action or inaction. As has already been indicated, the dialectical interaction between structure and agency is mediated through ideas and perceptions. The ideas and perceptions which agents use help them to construct socially their context, altering the structures and influencing others in this relationship. It is important to recall that power exercised by agency is a crucial factor of change. Following Foucault, WE argue that power is present in every social interaction.

There are many different mechanisms of social change which can be induced or promoted. The sources of these initiatives might be either external to the social group or structure, or they might be internal to the agency, or in some cases even a combination of both. Some may be more proactive or simply are in a better position, or have more resources to shape the agenda and get their preferences prioritised over others. Yet, this is not to say that the rest are powerless, because power is never a zero-sum game, in which the gain of one player represents the loss to his/her counterpart.

International organizations such as the IMF, the WB, the WTO, and the UN itself, have expanded their original limits. Since the post World War II years these organizations have exercised considerable leverage not only over international regimes, but also in inducing domestic changes for political procedures and economic restructuring. Additionally, domestic pressure groups and bureaucrats networking can also be identified within the boundaries of the State and many of 
them could extend their contacts beyond the borders; as is the case for nongovernmental organizations and a wide variety of different networks. Hence, networking makes evident alternative routes for the promotion of change, as sometimes they have brought specific concerns into the governmental agenda at different levels. It is discussed somewhere else networking can re-orientate, enhance, strengthen, and deepen the process of change (Cuadra-Montiel, 2007a). Social change needs to be processed endogenously both at the structural and at the agent level as well. War might dramatically modify the conditions for both the winners and the losers of the armed conflict, but it is not until the outcome of the confrontation has been internally digested and endogenously appropriated by the civil society that it can be accounted as an element of incremental, or sometimes abrupt, cumulative change. War is clearly a vital transformation factor in the processes of social change (Hay, 1996). It is also the crudest exercise of power. Whatever the aims of deploying warfare and exercising military muscle might be, a power factor supporting and promoting the use of violence can always be found. Since the destruction and reconstruction which military confrontation brings cannot be overlooked, war significantly shapes and transforms social processes, leaving its mark upon them. Not only is the use of violence one of the most dramatic ways in which change can be brutally imposed, but it also represents one of the most profitable businesses in the world, as the United States economy with its militaryindustrial complex makes evident. Still, it is necessary at this point to make explicit that this article does not explore processes of social change as a result of war or military confrontation. Rather, the emphasis is on non-violent punctuated evolutionary change. The mix of different mechanisms of coercion and consent clearly benefits some agents because neither governmental policies nor strategies are completely neutral. There is always some interest or preference privileged over others.

Social change necessarily must have an internal momentum and initiative, and also needs to be processed internally. It needs to become part of most, if not all the actors involved in the processes, otherwise it is only an alien element in the social pattern. Social change is also quite permeable and open to innumerable influences nevertheless, there are just a few which prove decisively important. Transformations can be induced or promoted from the structural context or from within the agency. The initiators or promoters of radical change could be located either at the top of the governmental or social structure or down among the grass roots. Thus, crucial in the implementation of changes are ideas, beliefs and perceptions, on which the actors stand and which make them act, selecting their preferences within a range of options.

In most cases, unidirectional trends or the convergence of policies, courses of action and decisions is not the only identifiable tendency. There are always countertendencies in play which, depending on the context, provide contingency and uncertainty for social processes, albeit to a different degree and depending on each one's specific circumstances. ${ }^{16} \mathrm{~A}$ dialectical understanding of interactions is helpful 
for portraying a broader, more comprehensive and detailed picture of the succession of events, and for process-tracing analysis.

Not only is the analytical perspective adopted here capable of tracing the features of processes; it is also well equipped to follow the strategic and discursive selectivity which mediates and influences social groups. ${ }^{17}$ Furthermore, and even more importantly, this theoretical approach analyses how the various elements leave distinctive imprints in such processes. What it is important to underline is the fact that, regardless of the original push or move to promote change, it always needs to be endogenously digested. Since the internally appropriated change modifies the agents' conditions and circumstances, it comes as no surprise that uncertainty, unpredictability and uneasiness are incorporated into the tendencies and countertendencies in play in the processes. The likelihood of unintended consequences arises due to tangible and intangible influences both for the strategically selective context and for the strategic actor. The intangible influences include institutions, interests, ideas and perceptions; which in turn modify the original input at different levels. The outcome might, or might not, retain all of the original characteristics. What is certain is that the outcome of the processes is seldom the intended one, due to the power present in all social interactions. Since no agent is powerless, each interaction made has an impact on some counterpart, albeit to a different extent. Accepting each interaction is case specific; the degree to which relationships are modified might alter the original aim. In this sense, the tendencies and countertendencies of the social interactions in play bring an uneasy, uncertain and unpredictable mix which makes social phenomena extremely difficult to reproduce. Since attention needs to be paid to the distinctive evolutionary features of social changes in process, we focus our argument on it in the following section.

\section{The extent of incremental punctuated evolutionary change}

One of the best ways to identify the transformative, adaptive and incremental character of changes in social processes is with the help of hindsight. Historical processes reveal trajectories otherwise impossible to perceive by means of static analyses. Crucial to the analysis of the tendencies and countertendencies of the processes are both the ideational and the material preconditions in which some of the causes and original motives could be identified; for history matters as much as the rest of the factors which the analyst identifies or selects. It comes as no surprise that a strong historical perspective, in which an adequate balance between theoretically informed and empirically grounded analysis must be pursued.

However, as has previously been emphasized, processes of social change do not move in a linear way. Unlike neoclassical economically oriented influences, equilibrium is very seldom if ever achieved in social processes. Moreover, iterative yet cumulative change is characteristic of interrupted evolution at different intervals by various phenomena and factors. Due to the fact that agency pursues contrasting agendas, it should not come as a surprise that forces seem to pull in contradictory directions all the time, and these reflect the immanent power exercised in social interactions. Nonetheless, these countertending patterns act dialectically and 
relationally as constituent elements of a more aggregated trend. Such scenarios are incompatible with the concerns for stability and equilibrium; although these in turn are perceived to be vital for economic and institutional restructuring efforts all over the world, v.g. economic restructuring in Mexico since the 1980's (Cuadra-Montiel, 2012 and 2016).

One point, however, should not be overlooked. The depth of social changes leaves traces at different levels. The fact that the analysis has hitherto concentrated on the macro level does not mean that the meso and the micro dimensions are ignored. This is simply an analytical distinction similar to others already mentioned, because all these levels are not segmented and clearly delimited in the daily interactions in the world out there. For the purposes of the current analysis the macro level of analysis is more appropriate; however, it is important to say that the other two dimensions are also incorporated in this work. For instance, political reforms, which are a small part of a broader democratization process, account for the recognition of every citizen's right to vote, elect, or abstain in choosing whomever they consider to best match their ideas and interests. Or it could be the case that no specific governmental programme is put into practice straight away. Rather it is mediated, influenced and modified by the agency involved, which sometimes dramatically alter the intended outcome. This brings indeterminacy and unintended consequences into play. The continuous interactions of situated actors in context present patterns of incremental evolution which characterize social processes, as represented symbolically in Figure 3 below.

Figure 3. Incremental evolution of social processes

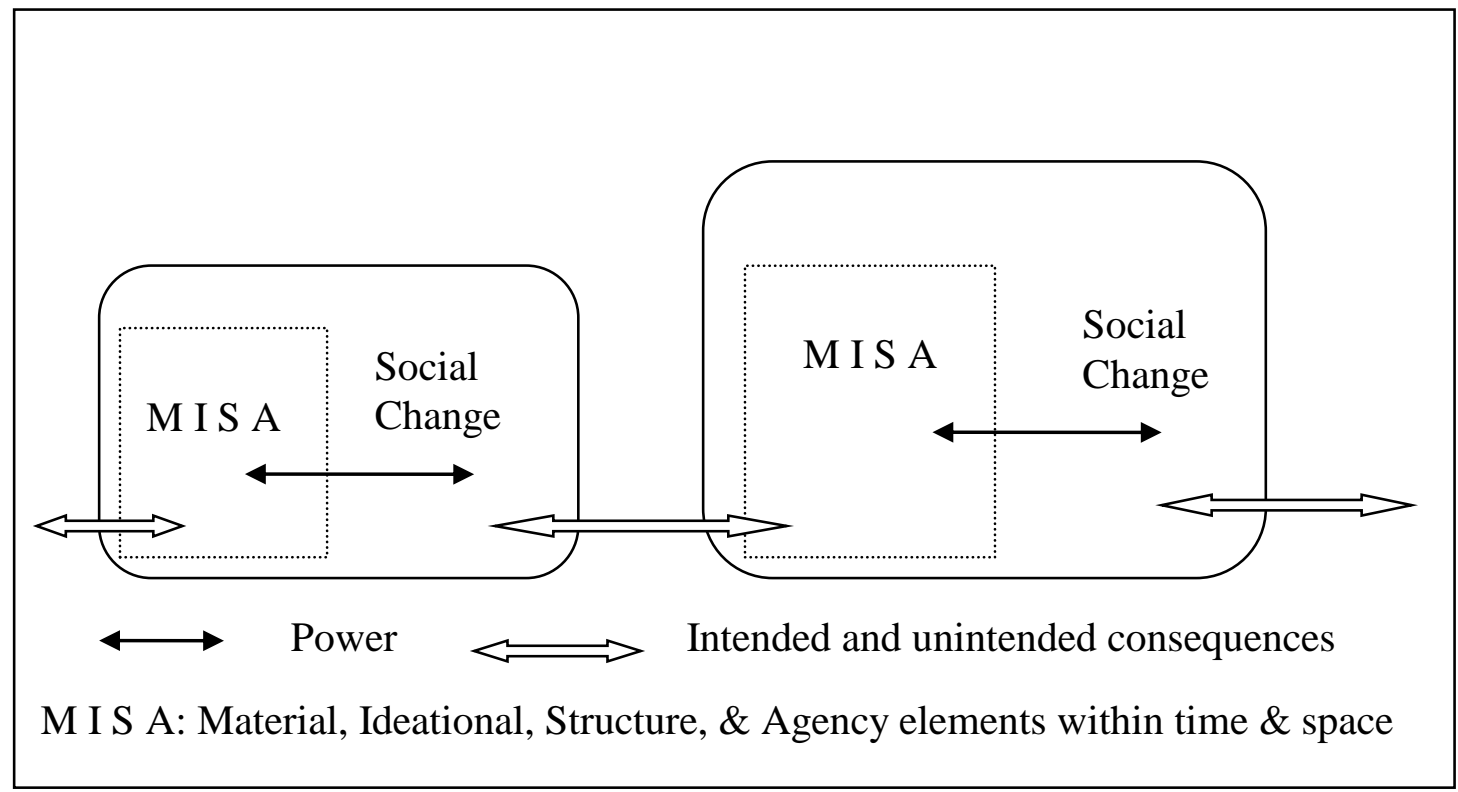


The social processes of punctuated evolution are never uniform or identical. On the contrary, their features and patterns are always evolving and could hardly be exhaustively listed. Nevertheless, it is possible to make a crude distinction between soft reformist and adaptive changes. This is similar to the distinction made by Hall between first and second order changes, on the one hand; and more transformative interactions, known as third order changes, on the other (1993). Since these theoretical distinctions have already been spelled out above, suffice it to say that throughout this work more emphasis is put on the transformative patterns of change which are more evident at the macro level. Reformist and adaptive changes, minor as compared to third order changes, can be better studied at the meso and micro levels of analysis.

Moreover, the present study does not deal with those latter dimensions in detail. An important caveat is needed at this point. Acknowledging that social interactions incrementally account for change, it is not the aim of the present study to X-ray microscopic interactions. Rather, it lays emphasis on more general patterns in a more balanced account of both the strategic and discursive selectivity which actors face in their interactions. As should be clear from the above, changes in ideas and emphasis on their implementation prove vital for the establishment or orientation of a subsequent institutional evolution trajectory. In this sense, it is not rare that some discourses emphasize external constraints for displacing responsibility whenever unpopular reforms are faced. Moreover, it is important to bear in mind that the case particularities at all levels increase the difficulty of making policies converge and the practices, standards and institutions harmonize.

Although it has been argued that the extent of social change remains open-ended, it is vital to stress that not every single input translates into an outcome. Since not all inputs automatically produce outputs, there might be some which might have no immediate direct effect at all. The explanation lies in the fact that there is no such thing as an automatic unidirectional linear mechanism in social interactions. Rather, it is more the iterated and cumulative cascade of first order and second order changes, which makes important adaptations or third order changes more likely and evident.

Furthermore, the fluid nature of the dialectical interactions between structural, agential, ideational, and material elements, although they are never free of contradictions, serve to maintain a momentum that seems sometimes either to accelerate or to slow down. Even though the eruption of crises or the perception of stability and equilibrium might seem consensual sometimes, it does not necessarily mean that the punctuated evolution of the social processes is exempt from countertendencies (Cuadra-Montiel, 2011).

\section{Final Comments}

The work presented in this article has been a theoretical enterprise aiming to provide an answer for the questions formulated at its outset. They are: What triggers social change? How does it happen? and, what are the factors which make changes evident? We have attempted to make explicit the immanent nature of power in all 
social relations. This is the core factor triggering change. Since it could be exercised by structural and agential sides, there is room for contingency and indeterminacy in the punctuated evolution of every social process of change. Furthermore, it has also been clearly stated that in order to keep these processes going it is necessary that change should be internally appropriated and incorporated into the social dynamics. The dialectical transformation of the original inputs into incremental outputs with intended and unintended consequences are, in turn, the raw materials for further subsequent interactions, i.e., social, political, and economic change neither starts, nor stops; it is ongoing.

Not only is the methodological emphasis on individualism on which neoclassical economic orthodoxy and rational choice models are founded not applicable to all human behaviour; it also neglects the existence of collectivities such as the government, or even the State. The problem of reification, that is providing human features to such collective actors make things even worse. This limitation, along with the problematic assumption that individuals always act rationally, making use of complete information in perfectly competitive markets free of uncertainty, is clearly inaccurate; however, there have been important attempts to escape these assumptions. Clearly, the understanding of social processes must not be reduced to narrow economic determinism. On the contrary, a comprehensive multidisciplinary approach to politics, allows us to trace the social processes of change and to identify power as a core factor which would otherwise be invisible. But this is not the same as claiming that its theoretical lenses are the only ones capable of identifying intangible factors.

It has also been argued that one merit of institutionalism is its incorporation of intangible elements such as rules into the analyses of political, economic and social sciences in general. Moreover, to acknowledge the difficulty of reforming or replacing embedded institutions clearly shows that such a task is beyond and cannot be reduced to merely instrumental self-interest (Hay, 2002). Despite this, acknowledging that institutions both as rules of the game, and that history matters are quite significant. Courses of action pursued in the past describe path-dependent patterns which have influence, even if not decisively determining the outcome for a contextualised agency.

It should be clear now that rational choice institutionalism is unable to provide adequate insight into the incremental and punctuated evolutionary patterns of social change. ${ }^{18}$ Since rules, legislation and regulations, as institutional rules of the game, are intangible elements, they play a major role, if not in directly shaping, at least in orientating or inducing the preferences and the contexts of the mental constructs of the agency to which they are targeted. These intangible elements work as the strategic and discursive mechanisms, which the actor in context takes into account for the formulation of strategy according to the strategically selective context he is situated in. Still, the perceptions, interpretations and social constructions of the world which the individual and collective actors are part of, prove vital, though they do not necessarily determine their choices. 
Nevertheless, the extent to which ideas contribute to alter or modify the material factors are just one part of the two-way interaction process between ideas and tangible elements. It is complemented by the impact which structures and agents make in the ideational sphere.

Since multiple factors and elements interact in all dimensions of the economic, political and social process, unpredictable and variable outcomes should not surprise anybody. Intended and unintended consequences are the results of ever-changing and fluid structural, agential, material and ideational factors reveals.

Even though structures are selective, they never determine social outcomes, for it is the actors who tend to select their preferred strategies within their own context. Outcomes are structurally undetermined and dependent on the selected strategies of either action or inaction by agency. In this sense, any chosen strategy is rooted in ideas, beliefs, information, interests and perceptions. Immaterial as all of them are, they have a real impact on the material dimensions of the social processes. They also act as triggers for the strategies and selected courses of action, both passive and active.

The analysis of different degrees of transformation, reform and adaptation could be identified as evidence of social change. Due to the overarching richness of the social processes and the exercise of power inherent in all social interactions, the elements which account for continuity and discontinuity can be identified. However, the sum of the parts might not equal the whole of the social processes of change. Moreover, the exercise of power inherent in all social interactions is the vital factor in the processes of social change. Nevertheless, it is important to mention that there are some qualitative differences between the actors. Even though agency is capable of displaying features of power immanent in her social relations, there are some actors who are in a better position to assert their priorities or preferences over others. Thus, this asymmetry does not neglect or cancel in any way the capacity and potential for other agents to challenge, modify, alter, or even radically transform the contexts and conditions in which they find themselves.

Recibido: 20/08/2018

Aceptado: 8/12/2018

\section{List of references}

Akerlof, George A. (1970), "The Market for 'Lemons': Quality Uncertainty and the Market Mechanism", in The Quarterly Journal of Economics, vol. 84, n³, August, pp. 488-500.

Blyth, Mark (1997), "'Any More Bright Ideas?' The Ideational Turn of Comparative Political Economy", in Comparative Politics, vol. 29, n¹, pp. 229-250.

Cammack, Paul (1992), "The New Institutionalism: Predatory Rule, Institutional Persistence, and Macro-Social Change", in Economy and Society, vol. 21, n⿳ 4 , pp. 397-429. 
Perspectivas Revista de Ciencias Sociales - ISSN 2525-1112|Año 3 No. 6 Julio-Diciembre 2018, pp. 78-100

Checkel, Jeffrey T. (1998), "The Constructivist Turn in International Relations Theory", in World Politics, vol. 50, January, pp. 324-348.

Cuadra Montiel, Héctor. (2016). "Power, State and Market in Mexico: A Polanyian Critique" Latin American Policy. vol. 7, no. 1, pp. 5-25.

Cuadra-Montiel, Héctor (2012), "Globalization and Re-commodification in Mexico", in Cuadra-Montiel, Héctor (ed.) Globalization - Approaches to Diversity. Croatia: InTech.

Cuadra-Montiel, Héctor (2011), "Demistifying Globalization and the State: Preliminary Comments on Re-commodification, Institutions and Innovation" in Pachura, Piotr. (ed.) The Systemic Dimension of Globalization, Croatia: InTech.

Cuadra-Montiel, Héctor (2009), "Social Change in Mexico: Re-politicizing the Agenda of Reform", in International Review of Sociology - Revue Internationale de Sociologie, vol. 19, $\mathrm{n}^{\circ}$ 3, pp. 411-432.

Cuadra-Montiel, Héctor (2008), "Where Does Mexico Stand? Interpreting NAFTA's Regional Scope and the FTAA Hemispheric Project", in Norteamérica, vol. 3, $\mathrm{n}^{\circ}$. 1, pp. 65-93.

Cuadra-Montiel, Héctor (2007a), "Critical Realism and the Strategic Relational Approach: Comments on a Non-Typical KWNS-SWPR Experience", in Journal of Critical Realism, vol. 6, n. 1, pp. 87-113.

Cuadra-Montiel, Héctor (2007b), "Incompleteness of Post-Washington Consensus: A Critique of Macroeconomic and Institutional Reforms", in International Studies vol. 44, $\mathrm{n}^{\circ}$. 2, pp. 103-122.

Foucault, Michel (1979), The History of Sexuality Vol. 1: An Introduction. (Translated by Robert Hurley), Harmondsworth: Penguin Books.

Foucault, Michel (1977), Discipline and Punish: The Birth of the Prison, London: Penguin Books.

Foucault, Michel (1976), “Two Lectures”, in Kelly, Michael (ed.) (1994), Critique and Power: Recasting the Foucault / Habermas Debate, Cambridge: The MIT Press.

Gill, Stephen (ed.) (1997), Globalization, Democratization and Multilateralism, New York: St. Martins Press and United Nations University Press.

Gill, Stephen (ed.) (1993), Gramsci, Historical Materialism and International Relations, Cambridge: Cambridge University Press.

Gilpin, Robert (2001), Global Political Economy: Understanding the International Economic Order, Princeton: Princeton University Press.

Hall, Peter A., and Taylor, Rosemary C. R. (1996), "Political Science and the Three New Institutionalisms", in Political Studies, vol. 54, pp. 936-957.

Hall, Peter A. (1993), "Policy Paradigms, Social Learning, and the State. The Case of Economic Policymaking in Britain", in Comparative Politics, vol. 25, April, pp. 275-296.

Hall, Peter A. (ed.) (1989), The Political Power of Economic Ideas: Keynesianism Across Nations, Princeton: Princeton University Press.

Hay, Colin. (2002), "Political Analysis: A Critical Introduction", Basingstoke: Palgrave.

Hay, Colin (2000), "What Place for Ideas in the Structure-Agency Debate? Globalisation as a 'Process Without a Subject'”, paper presented at the 
Perspectivas Revista de Ciencias Sociales - ISSN 2525-1112|Año 3 No. 6 Julio-Diciembre 2018, pp. 78-100

ESRC/JUC Research Training School, Evaluating Cutting Edge Social Science Research, Derwent College, University of York, 25 - 26 March 2000.

Hay, Colin (1996), Re-stating Social and Political Change, Buckingham: Open University Press.

Hay, Colin, and Richards, David (2000), "The Tangled Webs of Westminster and Whitehall: The Discourse, Strategy and Practice of Networking Within the British Core Executive", in Public Administration, vol. 78, n¹, pp. 1-28.

Hay, Colin, and Marsh, David (eds.) (2000), Demystifying Globalization, London: Macmillan / St Martins Press in association with POLSIS.

Hay, Colin, and Marsh, David (1999), "Introduction: Towards a New (International) Political Economy?", in New Political Economy, vol. 4, n¹, pp. 5-22.

Hay, Colin, and Wincott, Daniel (1998), "Structure, Agency and Historical Institutionalism”, in Political Studies, vol. 46, n5, pp. 951-957.

Held, David; McGrew, Anthony; Goldblatt, David; and Perraton, Jonathan (1999), Global Transformations: Politics, Economics and Culture, Cambridge: Polity Press.

International Monetary Fund (1999), “International Capital Markets. Developments, Prospects and Key Policy Issues", World Economic and Financial Surveys, by a Staff Team Led by Charles Adams, Donald J. Mathieson, and Garry Schinassi, Washington: Washington D.C.: IMF, September 1999.

Jessop, Bob (2002), The Future of the Capitalist State, Cambridge: Polity Press.

Jessop, Bob (1990), State Theory: Putting the Capitalist State in its Place, Cambridge: Polity Press.

Keynes, John Maynard (1936/1964), The General Theory of Employment, Interest and Money, London: Macmillan.

Lukes, Steven (1974), Power: A Radical View, London: The Macmillan Press.

Lawson, Tony (2003), Reorienting Economics, London: Routledge.

Lawson, Tony (1997), Economics and Reality, London: Routledge.

Marsh, David et al. (1999), Postwar British Politics in Perspective, Cambridge: Polity Press.

North, Douglass C. (1990a), Institutions, Institutional Change and Economic Performance, Cambridge: Cambridge University Press.

North, Douglass C. (1990b), "A Transaction Cost Theory of Politics", in Journal of Theoretical Politics, vol. 2, n4, pp. 355-367.

Ohmae, Kenichi. (1996), End of the Nation State: the Rise of Regional Economies, Special overseas edition, London: Harper Collins.

Ohmae, Kenichi. (1990), The Borderless World: Power and Strategy in the Interlinked Economy, London: Collins.

Peters, Guy B. (1999), Institutional Theory in Political Science: The 'New Institutionalism', London: Pinter.

Pierson, Paul (1993), "When Effect Becomes Cause: Policy Feedback and Political Change", in World Politics, vol. 45, n4, pp. 595-628.

Polanyi, Karl (1957), The Great Transformation: The Political and Economic Origins of our Time, Boston: Beacon Press. 
Perspectivas Revista de Ciencias Sociales - ISSN 2525-1112|Año 3 No. 6 Julio-Diciembre 2018, pp. 78-100

Rotschild, Michael; and Stiglitz, Joseph (1976), "Equilibrium in Competitive Insurance Markets: An Essay on the Economics of Imperfect Information", in The Quarterly Journal of Economic, vol. 90, n4, November, pp. 629-649.

Spence, Michael (1973), "Job Marketing Signaling”, in The Quarterly Journal of Economic, vol. 87, n`3, August, pp. 355-374.

Stiglitz, Joseph E. (2000), "Two Principles for the Next Round or, How to Bring Developing Countries in from the Cold”, in The World Economy, vol. 23, n 4, pp. 437-454.

Stiglitz, Joseph E. (1998a), More Instruments and Broader Goals: Moving Toward the Post-Washington Consensus, Helsinky: United Nations University, World Institute for Development Economics Research (WIDER annual lectures 2), January, 1998.

Stiglitz, Joseph E. (1998b), "Redefining the Role of the State: What Should it Do? How Should it Do it? And How Should These Decisions Be Made", paper presented on the Tenth Anniversary of MITI Research Institute, Tokyo: Japan, March, 1998.

Stiglitz, Joseph E. (1994), "The Role of the State in Financial Markets", in Report $n^{\circ}$ 14334, March, Washington D.C.: World Bank.

Stiglitz, Joseph E. (1991), "Another Century of Economic Science”, in The Economic Journal, vol. 101, n404, pp. 134-141.

Stiglitz, Joseph E. (1989), "On the Economic Role of the State" in Stiglitz, Joseph E. et al. The Economic Role of the State, (edited by Arnold Heertje), Cambridge: Basil Blackwell in association with Bank Insinger de Beaufort N.V.

Sztompka, Piotr (1993), The Sociology of Social Change, Oxford: Blackwell.

Watson, Matthew (2000), "The Political Discourse of Globalisation: Globalising Tendencies as Self-Induced External Enforcement Mechanisms", PhD Thesis, POLSIS, School of Social Sciences, The University of Birmingham.

Wendt, Alexander (1999), Social Theory of International Politics, Cambridge: Cambridge University Press.

Wendt, Alexander. (1992), "Anarchy is what States Make of it: The Social Construction of Power Politics", in International Organization, vol. 46, n², pp. 391-425.

\footnotetext{
1 The ontological and epistemological positions herein subscribed to are realist. The reason that structures do not determine outcomes is because agency always brings contingency and uncertainty into the social processes (Lawson, 1997 and 2003; Hay, 2002; Marsh et al., 1999). The politics of economic determinism are discussed in Cuadra-Montiel (2011).

${ }^{2}$ For the Mexican case see Cuadra-Montiel (2008, 2009, 2012 and 2016).

${ }^{3}$ Useful surveys are Cammack (1992); Hall et al. (1996); Hay et al. (1998); Peters (1999); and Pierson (1993).

${ }^{4}$ There seems to be some consensus about the importance of the relationship between institutions and behaviour, on one side, and how institutions originate and change on the other (Hall et al., 1996). Three great subdivisions of institutionalism are the historical, the rational choice, and the sociological.

${ }^{5}$ Shared features of the different institutionalist approaches are the consensus on institutions as both formal and informal structural features of society, and some concern for stability over time as well. Sharing a common ground of institutions as products of human agency, on the one hand, and the structure of rules and incentives as a 'choice of the designers' which limits the room for manoeuvre
} 
Perspectivas Revista de Ciencias Sociales - ISSN 2525-1112|Año 3 No. 6 Julio-Diciembre 2018, pp. 78-100

and shapes agency's behaviour, on the other, a detailed classification lists six different sorts of institutionalism: normative, rational choice, historical, empirical, international, and societal (Peters, 1999).

${ }^{6}$ Even though Pierson's work is considered representative of historical institutionalism, his notion of lock-in policy effects has strong similarities to rational choice institutionalism (1993).

7 The role which incentives and constraints play determines institutions themselves. Hence, the emergence of institutions follows a structural functionalist logic leaving aside agency in the explanation (Peters, 1999).

8 The property rights regime developed within the system is considered to be a fundamental set of market rules, and government is the best situated agency to make and enforce those rules which propel the function of the market (North, 1990a; and Peters, 1999).

${ }^{9}$ See Polanyi (1957) for a classic work on the origins of the market economy. Such a fascinting topic limited spaece does not allow us to discuss properly. The contemporary work of Stiglitz is illuminating on the roles of the state (v.g. 1989, 1991, 1994, 1998a, 1998b, and 2000). On information and market signals Rotschild and Stiglitz (1976) and Spence (1973) made relevant conributions.

10 Measurement and the costliness of enforcement are components of transaction costs. In addition to transformation costs, they equal production costs. Whenever it is expensive to transact the institutional rules of the game matter, as they become crucial factors in the performance of economies (North, 1990a and 1990b).

11 For rational choice institutional frameworks, change is completely alien to their explanations, and appears to happen only when institutions have fallen into obsolescence (Peters, 1999).

12 In Keynes' famous words: “...the ideas of economists and political philosophers, both when they are right and when they are wrong, are more powerful than is commonly understood. Indeed, the world is ruled by little else. Practical men, who believe themselves to be quite exempt from any intellectual influences, are usually the slaves of some defunct economist..." (1964:383).

13 The rise of monetarism as a challenger to the Keynesian policies in the late 1970s and early 1980s, could also be considered valid not only for developed countries, but also for the experiences of developing ones (Hall, 1993).

14 Actors' interests imply not only what the actors want and their motivations. Interests are also crucial elements of identity and complement who and what actors are (Wendt, 1999).

15 Some game theory analysis of cooperation makes use of static models. Iterated games imply the notion of repetition of the same material and ideational elements.

16 For example, nowadays social grass-root movements are recognized as political and social collective actors in their own right, able to exercise social power in its interactions.

17 Strategic selectivity refers to the contextual selection of some preferred means towards the achievement of a specific set of goals. (Hay, 1996 and 2002). In a similar way, the discursive selectivity, in turn, informs the actor to best formulate his/her strategies (Hay, 2002).

18 Institutionalism is not appropriate for the understanding of long-term social change, due to the predatory rule from governors and the institutional tendency to favour stability and the status quo (Cammack, 1992). 